\title{
Modernidad y barbarie en el pensamiento de C. G. Jung
}

José Ezcurdia Universidad de Guanajuato

\begin{abstract}
The following text reviews the diagnosis that Jung makes about a Modernity that feeds a 'shadow' or a terrible self-destructive power, because it does not allow the development of the contents of the colective unconscious. In this context the present article approaches notions such as symbol, archetype, 'self', wisdom, Apocalypse, and also Jung's critic to the churches and to the occidental rationalism. This notions and this critic are the conceptual frame from which Jung explains a Modernity that in its socialist, comunist and capitalist versions has given place to awful events such as the nazi's concentration camps, the sovietic Gulag, or the atomic bomb.
\end{abstract}

Keywords: symbol, archetypes, colective unconscious, modernity, apocalypse.

Resumen

El presente texto tiene como objeto revisar el diagnóstico que Jung realiza sobre una modernidad que al no permitir el desarrollo de los contenidos del registro anímico del inconsciente colectivo, cultiva una "sombra" que es fuente de un terrible poder autodestructivo. En este marco, se abordan nociones como símbolo, arquetipo, "sí mismo", sabiduría, apocalipsis, así como la crítica jungueana a las Iglesias y al racionalismo occidental. Estas nociones y dicha crítica constituyen el andamiaje conceptual a partir del 
cual Jung da cuenta de una modernidad que en sus versiones socialista, comunista y capitalista, ha dado lugar a hechos abominables como los alemanes campos de concentración, el Gulag soviético y la bomba atómica.

Palabras clave: símbolo, arquetipo, inconsciente colectivo, modernidad, apocalipsis.

ste texto busca recuperar algunas de las reflexiones que en torno
a la condición de la cultura moderna realiza Carl Gustav Jung. Somos conscientes de que en las últimas décadas la doctrina jungueana ha salido de la escena de los círculos académicos filosóficos, psicológicos y psicoanalíticos plegados a las corrientes de pensamiento preponderantes. Jung, como Mircea Eliade, ha hecho un esfuerzo por recuperar y valorar un pensamiento, permítasenos la expresión, arcaizante, que en múltiples sentidos desentona en el concierto de la reflexión contemporánea. Nosotros hemos abordado algunos tópicos de la doctrina de Jung con el afán de encaminarlos hacia un enriquecimiento del análisis de una modernidad que casi sistemáticamente prescinde de toda perspectiva como la arriba señalada para dar cuenta de sí misma y de hechos perturbadores que tienen lugar en su seno como lo fueron, por ejemplo, la Primera y la Segunda Guerra Mundial. Quizás un pensamiento como el de Jung nutra la de por sí rica, multipolar y compleja discusión sobre una modernidad también compleja y multipolar como a la que nos es dado asistir. Invitamos al lector a compartir nuestro modesto esfuerzo y a correr el riesgo que nosotros hemos corrido con el fin, en última instancia, de repensar una cultura moderna que a todas luces no deja de desafiar al pensamiento mismo. El presente texto está dividido en tres apartados. El primero aborda lo que podemos llamar la forma del vínculo del hombre con el arquetipo inconsciente. El segundo, el desarrollo del arquetipo en el hombre. Y el tercero, el diagnóstico que Jung realiza en torno a la condición de la cultura moderna. 
Jung, como Bergson, nutre un vitalismo filosófico en el que la vida, toda vez que aparece como fuente de la conciencia y la cultura, es objeto de un descuido, un menosprecio y un desconocimiento sostenidos que llevan a la conciencia y a la cultura misma a formas diversas de horror y decadencia. Jung concibe a la barbarie como la negación del desarrollo de un proceso vital en el que la intuición, el conocimiento y el cuidado de sí, al permitir a la vida dar el fruto que su forma supone - precisamente un hombre libre y una sociedad justa y amorosa - evitarían que la modernidad fuese la soga que al ser tirada ahorcará a la humanidad haciendo de la propia cultura occidental, sus regímenes políticos y su progreso tecnológico, formas de la autodestrucción y la muerte.

Veamos estos planteamientos más de cerca. Como es bien sabido por todos aquellos que se han acercado a Jung, para él psique y vida se identifican. Lo vivo es en esencia psíquico y lo psíquico, lo vital, tiene una estructura simbólica. En este sentido, el yo y la razón son manifestaciones de la vida, pero ésta no se reduce a ellos, y lo que es más, como veremos más adelante, por lo que resulta cierto endurecimiento y unilateralidad, pueden asfixiarla, limitando y pervirtiendo su cabal desenvolvimiento. La vida, según nuestro autor, tiene una estructura simbólica, y dicha estructura se constituye como el fundamento de la conciencia humana en sentido amplio, así como de las mencionadas formas del yo y la razón que, en último análisis, son productos recientes del proceso evolutivo y formas incipientes en la historia de la propia vida. La naturaleza y el contenido de los sueños y la mitología ${ }^{1}$ hacen inteligibles estas concepciones, pues revelan,

\footnotetext{
${ }^{1} \mathrm{Al}$ respecto cfr. Jaffé (1992: 53): “El método de investigación de Jung era preeminentemente histórico. Consistía, en esencia, en comparar ideas e intuiciones, y los esclarecimientos que había logrado del material empírico proporcionado por sus pacientes, con la evidencia histórica”.
} 
según Jung, la intencionalidad y el contenido del símbolo, en tanto estructura fundamental de la vida, que aparece como soporte de la conciencia humana. El carácter espontáneo de la vida onírica y el mito muestran la forma originaria de la vida, que en el propio símbolo condensa su propia forma en tanto fuerza psíquica. Jung señala en El hombre y sus simbolos:

Esa psique inmensamente vieja forma la base de nuestra mente, al igual que gran parte de la estructura de nuestro cuerpo se basa en el modelo anatómico general de los mamíferos. El ojo experto del anatomista o del biólogo encuentra en nuestro cuerpo muchos rastros de este modelo originario. El investigador experimentado de la mente de igual modo puede ver las analogías entre las imágenes oníricas del hombre moderno y los productos de la mente primitiva, sus "imágenes colectivas" y sus motivos mitológicos (2003: 66).

Desde la perspectiva de nuestro autor, los estratos más profundos de la psique se ordenan en una estructura simbólica que se manifiesta en sueños o en los relatos mitológicos. Esta estructura simbólica, en la medida que se encuentra imbricada con la trama de la vida, posee una forma impersonal, que Jung denomina "inconsciente colectivo": los símbolos o arquetipos se sitúan en una dimensión inconsciente y vital, que presenta una dinámica propia, anterior a la determinación de la propia conciencia racional y el yo.

Ahora bien, Jung señala que los símbolos inconscientes gozan de una profunda carga emotiva. No son simples imágenes, sino son energía psíquica con una función genética. Tienen una dimensión numinosa, pues son capaces de conmover a la voluntad e implican modificaciones en la personalidad de quien los experimenta. Jung nos dice en torno al carácter numinoso de los símbolos inconscientes:

Este argumento ilustra la forma en que aparecen los arquetipos en la experiencia práctica: son, al mismo tiempo, imágenes y emociones. Se puede hablar de un arquetipo sólo cuando estos dos aspectos son simultáneos. 
Cuando meramente se tiene una imagen, entonces es sólo una imagen oral de escasa importancia. Pero al estar cargada de emoción, la imagen gana numinosidad (o energía psíquica); se hace dinámica, y de ella han de salir consecuencias de alguna clase (2003: 94).

Los símbolos inconscientes, lejos de aparecer como meras imágenes producto de la imaginación o fantasía en el sentido peyorativo del término, al contar con una elevada carga psíquica y emocional, se constituyen como un elemento fundamental en la articulación de la personalidad. Desde la perspectiva jungueana, los símbolos inconscientes resultan un dato empírico fundamental a tomar en cuenta en la elaboración de cualquier análisis respecto de la forma y de los procesos de desarrollo tanto de la psique individual como de la cultura. Los símbolos son numinosos, pues son la vida misma que en tanto psique se desenvuelve en la conciencia del hombre.

Para nuestro autor, inconsciente y consciente presentan una serie de relaciones peculiares. El consciente toma del inconsciente motivos simbólicos fundamentales para su cabal desenvolvimiento. El inconsciente encuentra en el consciente el espacio para afirmarse. Una negación del consciente por el inconsciente deviene locura. Una negación del inconsciente por un exceso de conciencia, se constituye como fuente de neurosis. El adecuado vínculo y la circularidad entre los registros de la conciencia y el inconsciente son para Jung el principio de un equilibrado desarrollo del hombre y la sociedad. Jung nos dice al respecto: "En beneficio de la estabilidad mental y aun de la salud fisiológica, el inconsciente y la conciencia deben estar integralmente conectados y, por tanto, moverse en líneas paralelas. Si están separados o 'disociados', se derivará alteración psicológica” (2003: 45).

Para Jung, la adecuada complementariedad de las dimensiones del consciente y del inconsciente se traduce en un desarrollo del símbolo o arquetipo en la conciencia del individuo. Los símbolos expresados en sueños se constituyen como principios genéticos de la 
personalidad y la cultura. La negación de su propia forma genética en aras del sostenimiento de un proceso de homogeneización social o en vistas del mecánico cumplimiento de un deber moral, implica una interrupción de la propia circularidad consciente/inconsciente, con consecuencias negativas en la ulterior formación del carácter que es su ámbito de concreción.

El carácter mismo para Jung ha de concebirse en términos de tipo, huella, marca, grabación, que es producto del arqué del que es expresión. El arquetipo inconsciente es el resorte de la formación de un carácter que se construye en la medida que la conciencia misma manifiesta los contenidos del propio arquetipo. Así, la formación del carácter como una huella digital se realiza como un proceso de individuación, fundado en el peculiar desenvolvimiento que el hombre otorga al arquetipo. ${ }^{2}$ Jung en este sentido afirma:

Es sabido que en materia de religión no puede comprenderse nada que no se haya experimentado interiormente [...] De manera que si como psicólogo digo que Dios es un arquetipo, me refiero al tipo impreso en el alma, vocablo que, como es notorio, deriva de tipos=golpe, impresión, grabación (2002: 22).

Para Jung el símbolo se constituye como nexo de unión entre las dimensiones consciente e inconsciente de la psique. La sana circu-

\footnotetext{
${ }^{2} \mathrm{Al}$ respecto cfr. Jaffé (1992: 55): "En 1928, Jung comenzó a estudiar alquimia. Junto con su práctica, sus investigaciones científicas y los trabajos principales que había escrito en el ínterin, el trabajo acerca de su propio inconsciente había seguido avanzando. Su descubrimiento más importante durante estos años de experimentación fue el hecho de que estaba ocurriendo un proceso de desarrollo en el inconsciente que tenía como objetivo la plenitud de la personalidad. Este proceso (Jung más tarde lo llamó el 'proceso de individuación') con frecuencia se describe en la forma de imágenes del inconsciente que representan la circunvalación de un centro".
} 
lación de energía psíquica entre ambas dimensiones se traduce en un proceso de individuación en el que el sujeto construye su carácter en función de los contenidos del símbolo mismo, y no a partir de diversos esquemas impersonales ya sea racionales o sociales que bien pueden desviar o alterar los contenidos y la energía psíquica en el que aquel se constituye. La relación arquetipo-carácter clásica en la tradición neoplatónica es interpretada por Jung en clave psicológica, valiéndose de la asombrosa concordancia entre los materiales que ofrece la mitología y el mundo onírico.

Jung constata que al menos hasta la Ilustración no existe cultura sin religión y explica esta evidencia a partir de una psicología en la que el símbolo como forma interior de la vida hace posible la conciencia humana y ordena su forma en términos del desenvolvimiento de los contenidos que éste presenta. En este sentido Jung subraya:

Se puede percibir la energía específica de los arquetipos cuando experimentamos la peculiar fascinación que los acompaña. Parecen tener un hechizo especial. Tal cualidad peculiar es también característica de los complejos personales; y así como los complejos personales tienen su historia individual, lo mismo les ocurre a los complejos sociales de carácter arquetípico. Pero mientras los complejos personales jamás producen más que una inclinación personal, los arquetipos crean mitos, religiones y filosofías que influyen y caracterizan a naciones enteras y a épocas de la historia (2003: 76).

Jung apunta que el sueño y la mitología dotan a la naciente conciencia humana de una estructura fundamental y primera, alrededor de la cual se han formado las recientes figuras del yo y la razón. Todos los pueblos del planeta, antes que afirmar el yo y la razón misma, se han ordenado a partir de la función productiva y genética que revisten diversos símbolos primarios que como revisaremos en este texto, presentan una dinámica y una evolución característica.

Ahora bien, una vez avanzadas estas consideraciones preliminares en torno a las dimensiones del consciente y el inconsciente, a sus vínculos y relaciones, y sentada la importancia que Jung reconoce en 
el símbolo como fundamento genético y productivo de la personalidad y la cultura, podemos retomar el tópico general de este texto: ¿cuál es el perfil de una modernidad que ha hecho de la negación de las culturas tradicionales y su aparato simbólico el principio de su propia forma? ¿Una modernidad que en los ámbitos metafísico, epistemológico y científico, así como ético y político, ha privilegiado a la razón por sobre la sinrazón de la mitología y la vida inconsciente, es una cultura necesariamente civilizada, que ha logrado eliminar los horrores de la injusticia, la guerra y el exterminio? ¿Una modernidad que cancela sistemáticamente como vía de su propia articulación los nexos arquetipo-carácter es por definición una cultura civilizada que ha exorcizado los demonios de la guerra y la autodestrucción?

Jung señala que la obstrucción de una tendencia inconsciente, la represión de un símbolo genético de la personalidad y la cultura, equivale a su transmutación en una fuerza negativa que irrumpe de manera violenta en la conciencia. Nuestro autor señala que la modificación o inhibición del desarrollo de los procesos arquetípicos inconscientes genera una perversión de los mismos en términos de su manifestación no como principios justos del cabal desarrollo e integración de la identidad y el carácter, ya sea individual o social, sino de su afirmación ya sea en forma de neurosis o propiamente barbarie social.

Las iglesias y religiones institucionales en primer término, y el racionalismo moderno en segundo, han mediado perversamente u opacado el vínculo inmediato del sujeto y los pueblos occidentales con su vida anímica-arquetípica y sus símbolos, sentando las condiciones de una irrupción de los mismos como una "sombra" destructiva y alienante, que es la frustración efectiva de todo proceso de humanización. ${ }^{3}$ La sombra, para Jung, es la fuerza de un inconsciente

${ }^{3}$ En relación a los símbolos en los que se manifiesta la sombra, Joseph L. Henderson escribe "No obstante, el ego está en conflicto con la sombra, en lo que el 
reprimido que reclama de forma fáctica, avasallante y destructiva, la satisfacción su forma como impulso psíquico-vital. Nuestro autor señala al respecto:

Los símbolos inconscientes [...] Son integrantes de importancia de nuestra constitución mental y fuerzas vitales en la formación de la sociedad humana, y no pueden desarraigarse sin grave pérdida. Allí donde son reprimidos o desdeñados, su energía específica se sumerge en el inconsciente con consecuencias inexplicables (Jung, 2003: 90).

La represión de la carga psíquica y emotiva propia de los arquetipos inconscientes implica su transmutación en una sombra o energía anímica negativa que se manifiesta en la conciencia de manera abrupta y destructiva. Tanto la homogeneización de una sociedad debido a la imposición de una serie de valores morales heterónomos, como el imperioso cumplimiento del deber moral al que se puede ver sometido un individuo en aras de la satisfacción de normas diversas con una estructura puramente formal, dan lugar, según Jung, a la ruptura de las sanas relaciones entre el arquetipo y el carácter, propiciando la propia irrupción de la energía psíquica connatural al arquetipo mismo en forma de una férrea y unilateral afirmación o ciega potencia que atenta contra la vida del individuo y la sociedad. En cuanto al papel de las religiones institucionales y racionalismo occidental, Jung apunta:

doctor Jung llamó 'la batalla por la liberación'. En la lucha del hombre primitivo por alcanzar la conciencia, este conflicto se expresa por la contienda entre el héroe arquetípico y las cósmicas potencias del mal, personificada en dragones y otros monstruos. En el desarrollo de la conciencia individual, la figura del héroe representa los medios simbólicos con los que el ego surgiente sobrepasa la inercia de la mente inconsciente y libera al hombre maduro"(2003: 117). 
El budista deshecha el mundo de las fantasías inconscientes como ilusiones inútiles; el cristiano pone la Iglesia y la Biblia entre él y su inconsciente; y el intelectual racionalista ni siquiera sabe que su conciencia no es el total de su psique. Esta ignorancia persiste hoy día a pesar del hecho de que desde hace más de setenta años el inconsciente es un concepto científico básico que es indispensable para toda investigación psicológica seria (2003: 100).

Religión institucional y una razón que se concibe a sí misma como la totalidad de la conciencia o al menos como su parte fundamental son, para Jung, lastres de un hombre moderno que no hace una toma de contacto con su principio vital, entendido éste como la fuente justo de una conciencia que desenvuelve los arquetipos que son su matriz y horizonte de su estructura.

Ya sea al nivel individual o colectivo, la represión de la dimensión biológico-simbólica por las exigencias de una modernidad que privilegia el concepto al símbolo, la conciencia racional al vínculo activo con el inconsciente, aparece como origen de una neurosis que es el motor interior del exceso y la barbarie. Jung señala respecto al nivel de la psique individual:

Lo que llamamos conciencia civilizada se ha ido separando, de forma constante, de sus instintos básicos. Pero esos instintos no han desaparecido. Simplemente han perdido contacto con nuestra conciencia y, por tanto, se han visto obligados a hacerse valer mediante una forma indirecta. Esta puede ser por medio de síntomas físicos, en el caso de las neurosis, o por medio de incidentes de diversas clases, como inexplicables raptos de mal humor, olvidos inesperados o equivocaciones al hablar (2003: 80).

En relación al carácter de los pueblos inmersos en la propia modernidad afirma:

Nuestros tiempos han demostrado lo que significa abrir las puertas del inframundo. Cosas cuya enormidad nadie hubiera imaginado en la idílica inocencia del primer decenio de nuestro siglo han ocurrido y han trasto- 
cado nuestro mundo. Desde entonces, el mundo ha permanecido en estado de esquizofrenia. No sólo la civilizada Alemania vomitó su terrible primitivismo, sino que también Rusia está regida por él y África está en llamas. No es de admirar que Occidente se sienta incómodo (2003: 90).

Jung, al igual que Bergson, lleva a cabo la construcción de un vitalismo filosófico que tiene como objeto realizar un diagnóstico sobre una modernidad que muestra síntomas inequívocos de profundas alteraciones psicológicas. Jung, al hablar de modernidad y autodestrucción, tiene sobre la mesa nada menos que los horrores de la Primera y la Segunda Guerras Mundiales. Nazismo y comunismo le parecen manifestaciones de una conciencia que, al vertebrarse en la razón, no pudo dialogar de ningún modo con las fuerzas irracionales de la psique. Estas fuerzas, a base de ser negadas, irrumpieron en el panorama político-cultural de la sociedad moderna imprimiéndole el sello indeleble de la muerte y el horror. Jung nos dice por ello:

El hombre corre siempre el peligro — cada vez más— de no ver las realidades y las necesidades irracionales de su psique, y de creer que "puede hacer la cuenta sin contar con la huésped”; esto se ve de la manera más clara en las grandes empresas político-sociales tales como el socialismo y el comunismo (2007: 109).

Desde el punto de vista de Jung, ni la cultura en sentido amplio, ni ningún régimen político que se constituya como el férreo marco de una normalización que niegue al individuo la toma de contacto con su vida inconsciente, escapan al riesgo de degenerar en un sistema totalitario que incube una neurosis y una barbarie que se expresan en la guerra y el exterminio. En este sentido, a los excesos del nazismo y el comunismo, se suman los de un capitalismo en el que el comprar y el vender terminan por hacer del hombre la puerta de la manifestación de una insatisfacción vital por la cual la vida misma se degrada en violencia y odio. En este punto Jung subraya: 
Es ese estado de cosas el que explica el peculiar sentimiento de desamparo de tantas gentes de las sociedades occidentales. Han comenzado a darse cuenta de que las dificultades con las que nos enfrentamos son problemas morales y que los intentos para resolverlos con una política de acumulamiento de armas nucleares o de "competición" económica sirve de poco, porque corta los caminos (2003: 82).

El capitalismo es para Jung una formación cultural con una raíz tan deshumanizante como el fascismo o el comunismo, en tanto que se sostiene gracias a una serie de procesos económicos, que al constituirse como dispositivos represivos y normalizantes, desembocan en el sostenimiento de una estructura social y militar con un elevadísimo poder destructivo.

Como venimos diciendo, la sombra es para Jung resultado de una conciencia unilateral que no establece contacto alguno con la parte oculta de sí misma. Este contacto, desde la perspectiva de nuestro autor, permite el cabal desarrollo del arquetipo como principio constitutivo del carácter. En este sentido, la introspección, "el diálogo del alma consigo misma", es el fundamento de un adecuado vínculo del hombre con sus arquetipos inconscientes y de un feliz desarrollo del arquetipo en la conciencia. Esta capacidad dialógica de los planos consciente e inconsciente, Jung la denomina "ánima” y la identifica con el arquetipo de la diosa Sabiduría presente en la mitología. La diosa Sabiduría, que tradicionalmente se asocia con el aspecto femenino del arquetipo del "sí mismo" o Dios, implica la capacidad de transmutación de Dios mismo como sombra o ciega omnipotencia, en omnisciencia. La posibilidad de otorgar a la vida su manifestación como una conciencia íntegra que hace efectivos los contenidos de su sustrato arquetípico-inconsciente, está dada desde el punto de vista de Jung a través de una "sabiduría" que justamente en tanto diálogo del alma consigo misma, es decir, en tanto proceso de autoconocimiento, transmuta, simbólicamente hablando, a Dios como sombra, en un Dios que muestra un rostro amable y bondadoso. 
Jung hace expresos estos planteamientos en el texto Respuesta a Job. La acción de la diosa Sabiduría, que se hace posible por un ejercicio de anámnesis o rememoración, da lugar a un vínculo del hombre con el arquetipo de Dios o el "sí mismo". De esta forma, señala Jung, Yavé, dios iracundo, se manifiesta como un dios justo y amable. ${ }^{4}$ Jung encuentra en la mitología bíblica el material para elaborar sus concepciones psicológicas:

Dios ha sido conocido, y este conocimiento influyó en adelante no sólo en Yavé, sino también en los hombres. Por ello son los hombres de los últimos siglos precristianos los que, al leve roce de la Sabiduría preexistente, que sirve de compensación a Yavé y a su actitud, realizan a un tiempo la anámnesis de la Sabiduría. La sabiduría, que aparece altamente personificada y demuestra así su autonomía, se revela a los hombres como amiga suya, como ayudadora y abogado ante Yavé, y les muestra el aspecto luminoso, bondadoso, justo y amable de Dios (2007: 59).

El diálogo del alma consigo misma que simboliza la sabiduría asegura un vínculo efectivo del hombre con el arquetipo numinoso, de modo que dicho arquetipo encuentre un canal de libre desarrollo y no se vea constreñido por ninguna forma de represión que dé lugar a su manifestación como sombra o, para decirlo en términos de la propia mitología hebrea, como ira de Dios, que es fuente de temor y

\footnotetext{
4 "Lo que causó la mayor impresión en Jung fue la ambivalencia de la imagen de Dios judía. Se afirma que Javé es creador y destructor, benigno y severo, luz y tinieblas. A los ojos de Jung, la unión de estos opuestos extremos daba a los judíos una integridad superior a la imagen cristiana del Dios que es exclusivamente amoroso y amable. Jung sospechaba que había que buscar en esta diferencia la razón de la conservadora incapacidad de los judíos para aceptar el cristianismo. Sentía que su imagen de Dios era superior: expresaba la totalidad.

"Al considerar la ambivalencia de la imagen de Dios, Jung hizo la advertencia en repetidas ocasiones de que junto con el precepto cristiano del amor de Dios, deberíamos seguir el precepto del Antiguo Testamento del temor de Dios" (Jaffé, 1992: 99).
} 
temblor. La diosa Sabiduría, para Jung, equivale a la afirmación del arquetipo no como mera fuerza omnipotente sino, según hemos dicho, como una omnisciencia que supone un sujeto capaz de dialogar consigo mismo al llevar adelante una escucha a la voz y al mandato que supone el carácter numinoso de sus símbolos inconscientes. Para nuestro autor, el arquetipo, a la manera de una idea seminal, contiene en buena medida los trazos generales que ordenan la adecuada integración de la psique del sujeto, a pesar de que sea éste quien, en última instancia - no obstante su desconocimiento del arquetipo mismo por el carácter inconsciente que presenta-, resulte responsable de llevar adelante su desarrollo, sacando a la luz los contenidos peculiares que implica en tanto fundamento del desenvolvimiento del proceso de individuación. La escucha y la obediencia al mandato que revisten los símbolos inconscientes expresados en sueños o diversas experiencias estéticas o visionarias, se traduce en la acción de la diosa Sabiduría, habilitada para promover un diálogo del alma consigo misma que se resuelve en un vínculo de ésta con su principio genético, y en la inhibición de la manifestación de dicho principio como sombra. Nuestro autor hace expresos estos planteamientos en el texto Aión. Contribuciones al simbolismo del sí mismo:

Presumiblemente, el hombre conoce sólo una reducida parte de su psique, así como sólo tiene una muy restringida captación de la fisiología de su cuerpo. Como la causalidad de su existencia psíquica se sitúa en gran medida fuera de la conciencia, en procesos inconscientes, también operan en él determinaciones teleológicas que tienen del mismo modo en el inconsciente su origen y existencia (2006: 175).

Asimismo señala:

Por consiguiente, tanto causas como fines son trascendentes a la conciencia, en grado no desdeñable, lo que significa a la vez que su constitución y su actividad son inmodificables e ineliminables, mientras no se hagan objeto 
de conciencia y de decisión moral, por lo cual el conocimiento de sí es tan temido como necesario. Así pues, si despojamos a la citada frase del Fundamentum $^{5}$ de su ropaje teológico, viene a decir: la conciencia se ha hecho con el fin de que reconozca (laudet) su procedencia de una unidad más alta (Deum), preste a esa fuente solícita atención (reverentiam exhibeat), ejecute de modo inteligente y responsable sus prescripciones (serviat), y permita así a la psique en conjunto un óptimo de posibilidades de vida y desarrollo (savet anima suma) (2006: 175).

La asunción de los contenidos arquetípicos dados a la conciencia a través de los sueńos o relatos mitológicos, es para Jung el principio de una adecuada articulación de la conciencia misma, pues dicha asunción facilita y promueve la consecución de los motivos y los fines que estos presentan en tanto desarrollo de la vida misma que se expresa en el sujeto. La mitología y la religión, en este sentido, muestran en un ropaje simbólico lo que la psicología profunda establece a partir de los modernos términos de consciente e inconsciente: que el conocimiento de sí es un fenómeno a la vez psicológico y vital, pues es la vida y sus símbolos el objeto de aquellos procesos introspectivos que brindan al hombre la posibilidad de llevar a cabo una integración de su personalidad, en la cual las partes desconocidas u oscuras de su propia psique no irrumpan de manera avasallante y desgarradora.

${ }^{5}$ Jung extrae de los Exercitia spiritualia de San Ignacio de Loyola el siguiente texto: "El hombre ha sido creado [con este fin:] para que alabe a Dios nuestro señor, le demuestre reverencia, le sirva y salve así su alma”. Una vez citado el texto de Ignacio de Loyola, establece que es desde una perspectiva psicológica y racional, y no teológica, que se debe interpretar, para hacer efectivo justo su rendimiento vital: "Esta traducción no sólo en cierto modo suena, sino que debe ser racionalista, es decir, conforme a la razón, pues el espíritu moderno, pese a serios esfuerzos, ya no entiende el lenguaje teológico, que data de casi dos mil ańos atrás. No sólo amenaza, sino que se ha instalado hace tiempo, el peligro de que esa falta de comprensión sea sustituida o por la inautenticidad del sentir, la afectación y una fe forzada, o bien por la resignación y la indiferencia” (2006: 176). 
El autoconocimiento es para Jung la actualización en la conciencia del tipo que se constituye como su principio genético. En este sentido, el autoconocimiento y el proceso de individuación que éste implica, se satisfacen justo como el vínculo armónico entre las dimensiones consciente e inconsciente de la psique. Jung reprocha a la cultura moderna, de este modo, precisamente la cancelación de todo espacio de autoconocimiento e introspección por un racionalismo y una economía de mercado, que deja de lado las necesidades más profundas de la psique misma, entendidas éstas como el desarrollo del principio vital en el que se constituye:

Me he pasado más de medio siglo investigando los símbolos naturales y he llegado a la conclusión de que los sueños y sus símbolos no son estúpidos y sin significado. Al contrario, los sueños proporcionan la más interesante información para quienes se toman la molestia de comprender sus símbolos. Cierto es que los resultados tienen poco que ver con esas preocupaciones mundanas de comprar y vender. Pero el significado de la vida no está exhaustivamente explicado con nuestro modo de ganarnos la vida, ni el profundo deseo del corazón humano se sacia con una cuenta bancaria (2003: 101).

Autoconocimiento es para Jung sinónimo de vida, pues gracias a éste la energía psíquica propia del símbolo arquetípico encuentra las vías idóneas para asegurar la concreción de sus contenidos, evitando así su perversión y su manifestación bajo formas degradadas y autodestructivas que no gozan de la autoconciencia y la autonomía moral que supone un individuo responsable, capaz de gobernar y dar cuenta de sus actos y sus emociones. El sujeto, al atender al llamado de su inconsciente, da cumplimiento a un conocimiento de sí, que redunda en la formación de un carácter articulado en una capacidad de autodeterminación. La autoarquía, como corazón de la moral autónoma, radica en este sentido en el desenvolvimiento del arquetipo como principio del ethos o carácter, en tanto consecución consciente de un destino que es la vida misma que se desenvuelve en el sujeto. 
Llegados a este punto es importante señalar que desde la perspectiva de nuestro autor, el propio conocimiento de sí, la acción de la diosa Sabiduría, implica no sólo, como hemos dicho, el vínculo del hombre con el arquetipo o la vida, sino la transformación de la vida misma gracias al vínculo que el hombre establece con ella. En otros términos, la diosa Sabiduría y, con ésta, la transmutación de la ira de Dios en una carga psíquica benéfica para el sujeto, supone la metamorfosis de la vida misma que sólo en su manifestación encuentra el envite para conquistarse a sí misma como autoconciencia.

Jung nos muestra estos planteamientos al señalar la separación de Yavé y la diosa Sabiduría. Para Jung, la vida no necesariamente se determina como conciencia. Esta conciencia se obtendrá justo a través de la figura del hombre:

Mientras que los hombres, bajo esta dura disciplina, se aplican a ensanchar su conciencia mediante la adquisición de cierta sabiduría, es decir, mediante la adquisición, en primer lugar, de prudencia y circunspección, este mismo proceso histórico hace patente que Yavé ha perdido de vista, desde los días de la creación, su coexistencia pleromática con la Sabiduría (2007: 57).

Para Jung, no sólo el hombre tiene el reto de escuchar la vida que en tanto estructura simbólica le brinda los senderos para dar lugar a la integración de su carácter, sino que la vida misma, gracias a la diosa Sabiduría - a la prudencia y a la circunspección que implica todo proceso de autoconocimiento- encuentra un desarrollo de su forma como una conciencia de sí, que se resuelve en la articulación de su naturaleza tanto como omnipotencia, como omnisciencia.

Jung hace expresas estas concepciones al señalar que Job, al reclamar a Dios su injusticia, se determina como el espejo en el que Dios se reconoce como tal y gana precisamente una conciencia que es el desenvolvimiento de los contenidos de su naturaleza psíquica: 
El carácter que se patentiza en todo esto es el carácter propio de una personalidad que sólo mediante un objeto puede sentir su propia existencia. La dependencia del objeto es absoluta en cuanto el sujeto no posee autorreflexión, y, en consecuencia, no posee tampoco visión alguna sobre sí mismo; parece como si el sujeto sólo existiese al tener un objeto que le asegure que existe. Si Yavé poseyese realmente conciencia de sí mismo —que es lo menos que podría esperarse de un hombre inteligente- se habría opuesto, a la vista de las verdaderas circunstancias, a que se alabase su justicia. Pero Yavé es demasiado inconsciente para ser "moral". La moralidad presupone la conciencia (2007: 25).

Desde el punto de vista jungueano el análisis simbólico de la tradición judeocristiana — tradición que aparece como la matriz en la que tiene su emergencia la propia cultura moderna - revela una tensión interior y una relación dialéctica entre la forma de la vida o el arquetipo del "sí mismo" y el hombre, en la medida que la toma de conciencia del hombre al ser responsable de sí a partir de su vínculo con su principio, se traduce también en la transmutación de ese principio que se gana como conciencia justo gracias a la propia negatividad que le ofrece el hombre mismo. El estudio de los símbolos o arquetipos muestra una tensión inherente a la forma de la vida, en la medida en que la relación entre el símbolo mismo y la conciencia, se funda en una estructura procesual en el que ambos se codeterminan e implican mutuamente, dando como resultado un mutuo progreso y su fusión en una unidad de conciencia más alta.

Precisamente resultado de este progreso, señala Jung, es el arquetipo del "gran hombre" o el héroe, que constituye una realización más o menos completa de la forma misma del arquetipo como conciencia. El arquetipo del gran hombre o el héroe, como momento fundamental en prácticamente todas las mitologías del globo — Buda, Krishna, Quetzalcóatl, etc. - en la tradición judeocristiana se presenta en la figura de Cristo. Cristo, desde la perspectiva de Jung, se determina como respuesta del reclamo de Job a Yavé por su injusticia, reclamo 
que emplaza a Dios a articularse no sólo como ciega omnipotencia, sino justo como omnisciencia. Jung nos dice en Respuesta a Job:

El acercamiento de la sabiduría significa una nueva encarnación. Pero esta vez no es el mundo el que debe ser cambiado; es Dios el que quiere transformar su propia esencia. Ahora la humanidad no ha de ser aniquilada, como antes, sino salvada. En aquella decisión de encarnarse se percibe el influjo, favorable a los hombres, de la sabiduría. Ahora no han de ser creados nuevos hombres, sino Uno: el hombre-Dios (61).

Desde el punto de vista de Jung, Cristo, en tanto símbolo arquetípico, revela una progresión de la vida en conciencia ya que supone la reconciliación de Dios con la figura de la sabiduría, que había sido cancelada por el olvido y el desgarramiento constitutivo de Dios bajo la forma de la inconciencia o el propio Satán.

En este marco, apunta Jung, la diosa Sabiduría es el principio de la afirmación de Dios como un dios de amor. Dios, al reconocer el reclamo de Job y responder encarnándose en su hijo, escucha la voz de la sabiduría, dando lugar a su forma como una arquetipo misericordioso capaz de traer la justicia sobre la tierra. Jung señala al respecto:

En lo que se refiere al aspecto humano de Cristo — si es que se puede hablar en absoluto de un aspecto únicamente humano- - se destaca de manera harto clara su "filantropía". Este rasgo está ya insinuado en la relación de María con la Sabiduría y, además, de manera especial, en la procreación de Cristo por el Espíritu Santo, cuya naturaleza femenina está personificada por la Sabiduría, ya que ella es el modelo histórico inmediato del agios pneuma, el cual es simbolizado por la paloma, el ave de la diosa del amor (2007: 76).

\section{Asimismo apunta:}

La acentuación de la edad de Dios está en conexión lógica con la existencia de su hijo, pero insinúa también la idea de que Dios debe pasar a un segundo plano y que el hijo debe ir tomando cada vez más las riendas del mundo de los hombres, de lo cual se espera un orden más justo (2007: 105). 
Jung lleva a cabo un análisis psicológico de la simbología de la transición del Antiguo al Nuevo Testamento, para rastrear la génesis de las nociones de amor y justicia que se constituyen como directrices fundamentales de la cultura occidental.

Ahora bien, en este punto, Jung es cuidadoso en subrayar que el proceso psíquico trazado en la evolución dialéctica Yavé-Satán, Yavé-Job, Yavé-Sabiduría-Cristo, de ninguna manera se encuentra cancelado. Aún dado el motivo de la encarnación, el hombre no se identifica con Cristo, ni Cristo constituye la completa satisfacción de Dios o la Vida como conciencia. Estos planteamientos tienen su fundamento en la simbología del Nuevo Testamento y en particular en la del Apocalipsis de San Juan, donde la ira de Dios se manifiesta incontestablemente al fin de los tiempos, rebasando interiormente la caracterización de Dios mismo en tanto Cristo justo como un dios de amor. Jung apunta en este sentido:

Hay que conceder que sería contrario a toda esperanza racional que Dios, que desde los primeros tiempos ha venido entregándose, junto a la generosidad, también a devastadores ataques de ira, se convirtiese ahora de repente en la síntesis de todo lo bueno. La duda, no confesada, pero no por ello menos clara, de Cristo en este sentido se encuentra confirmada en el Nuevo Testamento, en el Apocalipsis de San Juan (2007: 83).

Jung ve en las visiones de San Juan el dato a partir del cual señala que el proceso vital relativo a la encarnación se encuentra incompleto, en el sentido de que el lado oscuro de la conciencia del hombre, su sombra, y el lado oscuro de la conciencia del arquetipo del "sí mismo”, Satán, no han dado lugar a una nueva reconfiguración que, gracias a la diosa de la sabiduría, pudiera exorcizar de la psique del hombre los horrores característicos de la ira de Dios, que en el propio lenguaje bíblico, aparecen bajo la simbología de los Jinetes del Apocalipsis. 
El Apocalipsis de San Juan ilustra, desde el análisis psicológico-arquetípico jungueano, los poderes destructivos inherentes a la conciencia del hombre moderno que, gracias a la diosa Sabiduría, bien pudieran transmutarse en una forma más amplia de amor, que salvara a la humanidad de su propia destrucción. Para esclarecer estas afirmaciones retomemos las consideraciones preliminares en torno al papel de la Iglesia en Occidente, y al lugar que tiene la industria bélica y la tecnología en una modernidad en la que la sombra posee un función activa en la formación de la cultura.

\section{III}

Para Jung las Iglesias católica y protestante, en vez de promover una adecuada relación consciente-arquetipo del hombre occidental, satisfaciendo el sentido fundamental del planteamiento religioso en tanto una experiencia del alma, establecen una serie de dogmas rígidos y esquemáticos en vistas de la conservación del poder institucional que les confiere sostener sendas jerarquías político-sociales con base en la manipulación de las estructuras inconscientes del sujeto. Según Jung las Iglesias en mayor o menor medida niegan la figura de la esposa de Cristo o esposa de Dios, en tanto enaltecimiento de la diosa Sabiduría, que supondría justo la manifestación acabada del diálogo de Dios consigo mismo, que equivaldría a su completa determinación como omnisciencia. A pesar de que la Iglesia católica ha establecido el culto mariano, ésta, como las Iglesias protestantes, se constituye en un falocentrismo que relega a la mujer a un papel secundario, castrando el aspecto femenino del arquetipo, la propia sabiduría, por la cual éste encontraría su completo desarrollo como conciencia de sí. Jung nos dice al respecto:

Las consecuencias de la declaración pontificia no pueden escamotearse y hacen que el punto de vista protestante quede abandonado al odium de 
una simple religión de varones, que no conoce ninguna representación de la mujer, algo semejante al mitraísmo, al que este prejuicio acarreó muchas desventajas. Es claro que el protestantismo no ha prestado atención suficiente a las señales de la época, las cuales apuntan hacia la igualdad de los derechos de la mujer. Esta igualdad de derechos tiende a alcanzar una fundamentación metafísica en la figura de la "mujer divina", de la esposa de Cristo (2007: 161).

Para Jung, la Iglesia escamotea a la conciencia humana la posibilidad de afirmarse como ámbito de desarrollo del arquetipo del "sí mismo", pues cancela el aspecto femenino de éste con el fin de promover la sola parte masculina. De este modo, el diálogo del alma consigo misma simbolizada por la figura de la diosa Sabiduría, se ve cercenado dentro del circuito consciente-inconsciente, en tanto principio del desarrollo del hombre como del propio arquetipo de la divinidad.

Para Jung es la unión de los contrarios el símbolo que señala la cabal promoción de la conciencia en tanto ámbito de metamorfosis y plenificación del arquetipo del "sí mismo". La unión del Sol y la Luna, Isis y Osiris, y el propio Dios-Cristo con la sabiduría simbolizada por María, expresa el cumplimiento de la hierogamia o las bodas celestiales en quien Dios se reconoce a la vez como omnipotencia y omnisciencia, como perfección y totalidad que manifiesta una acabada autoconciencia. ${ }^{6} \mathrm{La}$ encarnación de Dios en Cristo, desde el punto de vista de un análisis de los arquetipos inconscientes, ha de

${ }^{6}$ Jung (2007: 59) nos dice al respecto: "La perfección es un desideratum masculino, mientras que la mujer se inclina hacia la plenitud o totalidad. En efecto, todavía hoy el varón puede soportar mejor y por más largo tiempo una relativa perfección, mientras que, generalmente, a la mujer la perfección no le viene bien, y aun puede resultarle peligrosa. Cuando la mujer aspira hacia la perfección, olvida su función complementadora, su función de totalidad, la cual es en sí imperfecta, pero por ello mismo constituye el necesario contrapolo de la perfección. De la misma manera que la totalidad es siempre imperfecta, la perfección es siempre incompleta”. 
desenvolverse en la divinización de la sabiduría, de María, el aspecto femenino de Dios, en tanto diosa-madre y esposa de Cristo. Jung nos dice al respecto:

La sabiduría es el "artífice", ella realiza los pensamientos de Dios, dándoles forma material, lo cual es una prerrogativa absoluta del ser femenino. Su coexistencia con Yavé significa la eterna hierogamia, en la que los mundos son engendrados y procreados. Nos encontramos ahora ante una gran transformación: Dios quiere renovarse en el misterio de las bodas celestiales [...] y quiere hacerse hombre (2007: 60).

Para Jung, el símbolo del hermafrodita representa la culminación de una relación arquetipo-conciencia en la que ambos términos encuentran en su opuesto la negatividad para desarrollarse, cobrar conciencia de sí, y vincularse el uno con el otro, justo bajo la forma de la unión de los opuestos.7 El mito del hermafrodita de Platón en El banquete, el maridaje de Isis y Osiris, la unión del Sol y la Luna, son buenos ejemplos de ello. Desde el punto de vista jungueano, Occidente no ha podido, por el predominio de la omnipotencia sobre la omnisciencia fundada en el falocentrismo eclesiástico y racionalista, desenvolver los contenidos de la diosa Sabiduría como diálogo del alma consigo misma, de modo que realice al propio arquetipo del "sí mismo" justo como unión de los opuestos. ${ }^{8}$ Por ello, señala nuestro autor, Occidente se encuentra expuesto a los peligros de la ira de

\footnotetext{
${ }^{7}$ Al respecto cfr. Jaffé (1992: 64): “Detrás del vínculo entre los sexos está el 'sí mismo', el arquetipo del todo, que contiene y al mismo tiempo une los opuestos en la naturaleza humana. Esta dualidad y unidad están expresadas en el lenguaje figurativo de la alquimia por medio de pares de opuestos como Rex y Regina, Adán y Eva, Sol y Luna, ave y víbora, o por medio del concepto más general y abstracto de una coincidentia opposituorum".

${ }^{8}$ La cuestión de la unión de los contrarios resulta nodal en la analítica arquetípica jungueana. Al respecto cfr. Psicología y alquimia donde nuestro autor señala: "La androgenia de Cristo es la concesión extrema que hizo la Iglesia a la problemática
} 
Dios que se encuentran amplificados por el propio despliegue tecnológico. El Apocalipsis, en este sentido, se constituye como la imagen que toda vez que anuncia el ascenso de María al rango de diosa, muestra la ira de Dios como negatividad que bien puede terrible y trágicamente impeler al hombre a desarrollar los contenidos justo de su parte femenina, concebida ésta como una profundización de su capacidad de autoconocimiento. Jung apunta al respecto en Respuesta a Job:

Por esta razón el Apocalipsis, lo mismo que todo proceso clásico de individuación concluye con el símbolo de la hierogamia, de las nupcias del hijo con la esposa-madre. [...] Este es el programa del eón cristiano, que ha de realizarse antes de que Dios pueda encarnarse en el hombre creatural. Sólo en los últimos tiempos se cumplirá la visión de la mujer vestida de Sol [...] De esta manera San Juan esbozó el programa de todo el eón de los peces con su dramática enantiodromía y su oscuro fin, que todavía no hemos vivido, y ante cuyas posibilidades verdaderamente apocalípticas el hombre se estremece. Los cuatro funestos jinetes, los amenazadores toques de trompetas, las copas de la cólera que han de ser vertidas sobre el mundo: todo esto es algo ya inminente, es algo todavía inminente. La bomba atómica está suspendida sobre nuestras cabezas como una espada de Damocles, y detrás de ella acechan las posibilidades, incomparablemente más terribles, de la guerra química, que podrían eclipsar los horrores del Apocalipsis (140).

Para Jung, la modernidad se encuentra frente a la posibilidad de su autodestrucción o al menos de un casi completo autoaniquilamiento, en la media que sus instituciones religiosas y políticas niegan el desarrollo de los arquetipos inconscientes que son su fundamento.

de los opuestos. La contraposición de lo luminoso y bueno, por un lado, y de lo oscuro y malo, por otro, quedó abandonada abiertamente a su conflicto en cuanto Cristo representa el bien sin más, y el opositor de Cristo, el diablo, representa el mal. Esta oposición es propiamente el verdadero problema universal, que aun no ha sido resuelto. El selbst (sí mismo), empero, es una paradoja absoluta, pues desde cualquier punto de vista que se lo considere, representa tesis y antítesis, y al propio tiempo síntesis" (30). 
Jung concibe la modernidad como un momento - el momento de la negatividad o la antítesis - del movimiento pendular en el que se agudizará justo la tensión interior de la relación hombre-vida, a partir del cual ésta ha de hacer florecer su forma como conciencia de sí. El Renacimiento, la Ilustración, el ascenso de la nueva ciencia, se constituyen como expresión de la figura de una sombra que viene a espolonear a la era cristiana, precipitando su reformulación como una religión hierógamica en la que lo femenino venga a concretar la forma de una conciencia autotransparente capaz de dialogar consigo misma. Revisemos los planteamientos que Jung hace al respecto:

El ideal de la espiritualización [medieval] que urge hacia lo alto había de ser desvirtuado por la pasión materialista, enteramente sujeta a la tierra, de dominar la naturaleza material y conquistar el Universo. Esta transformación se hizo manifiesta en la época del Renacimiento, término con el cual se entendía la restauración del espíritu antiguo. Hoy se sabe que esto era principalmente una máscara, y que lo renacido no era el espíritu antiguo sino más bien el cristiano medieval, el cual, asumiendo singulares aires paganos, sufrió una transformación, trocando el objetivo celeste por un objetivo terreno y pasando con ello de la verticalidad del estilo gótico a la horizontalidad del descubrimiento de la naturaleza y el mundo. El desarrollo ulterior, que llevó a la Ilustración y a la Revolución Francesa, ha producido hoy un estado de expansión mundial que no puede llamarse sino anticristiano, corroborando así la anticipación cristiana del "fin de los tiempos" (56).

Jung ve en los procesos históricos de la Edad Media y la modernidad momentos del desenvolvimiento del arquetipo del "sí mismo" en el hombre, desenvolvimiento que se articula a través del establecimiento de una serie de oposiciones (Yavé-Job, Cristo-María, Medievo-Ilustración) que implican la evolución del propio arquetipo y del hombre bajo una conciencia de sí, que se hace posible precisamente por el diálogo del alma consigo misma. Jung se vale de la psicología arquetípica para establecer una filosofía de la historia en la que elementos platónicos se imbrican con una recuperación 
de la historicidad característica del judeocristianismo, estableciendo las condiciones para realizar un diagnóstico sobre una modernidad que bajo los paradigmas del progreso y la ciencia, oculta una terrible barbarie que tiene como pequeño botón de muestra, los horrores del holocausto nazi.

Para Jung, el problema fundamental del hombre moderno es llevar o no hasta sus últimas consecuencias el despliegue racional. La razón, según él, por sí misma es una gran herramienta de la evolución de la conciencia y un formidable aparato adaptativo. Sin embargo, la vía de satisfacción de dicha evolución se encuentra en el nivel de las imágenes inconscientes que determinan la vida del hombre. Es sólo a partir de estas imágenes que, por su aspecto numinoso, capaz de conmover a la voluntad, el hombre podrá dar lugar a una moral que lo sustraiga a los excesos derivados de un desconocimiento del poder destructivo de su inconsciente. Jung nos dice al respecto:

El problema es ahora el problema del hombre. El hombre tiene en sus manos una terrible fuerza de destrucción; el problema consiste en si podrá resistir al deseo de usarla, en si podrá refrenar este deseo con el espíritu del amor y de la sabiduría. [...] Sea cualquiera la significación de la totalidad del hombre, del "Sí mismo", empíricamente esta totalidad es una imagen, producida de manera espontánea por el inconsciente, de la meta de la vida, y está más allá de los deseos y de los temores de la conciencia. Esta totalidad representa la meta a que ha de llegar todo hombre, con o contra la conciencia (2007: 153).

Para Jung, como para Bergson y el conjunto de la tradición vitalista, la razón no basta para dar lugar a un valor moral habilitado para reconducir a la emoción y seducir a la voluntad. Es la intuición de una imagen o un símbolo el principio para dotar a la propia voluntad y al entendimiento de una carga emotiva y un sentido capaz de constituirse como resorte efectivo de la autonomía moral. La intuición en tanto clave fundamental de todo proceso de autoconocimiento es, según Jung, la vía para acceder a la aprehensión inmediata de aquellas 
imágenes o arquetipos constitutivos que bien pueden promover un progreso moral que otorgue al hombre justo una responsabilidad y un gobierno de sí que lo sustraiga del riesgo de una autodestrucción masiva detonada por un uso irracional del progreso tecnológico.

Jung critica la falta de introspección del hombre moderno y con ella su incapacidad de conocerse a sí mismo, de elevar la sabiduría al rango de una diosa, de modo que, como en un espejo, reconociese una libertad interior, que lo hiciera dejar su condición autodestructiva y de terrible barbarie. Mientras Occidente a través de sus Iglesias haga uso de los arquetipos inconscientes como herramientas de dominación y de la razón un instrumento de la represión que da lugar a la sombra, no podrá dar a luz un carácter propio que refleje la conquista de un destino liberador.

\section{Bibliografía}

Bergson, Henri, 1991, Las dos fuentes de la moral y la religión, PUF, París.

Eliade, Mircea, 1976, El chamanismo y las técnicas arcaicas del éxtasis, FCE, México.

Franz, Marie-Louise Von, 1995, Sobre los sueños y la muerte, Kairós, Barcelona.

Freud, Sigmund y Carl Gustav Jung, 2000, Correspondencia, Paidós, Barcelona. Jacobi, Jolande, 2003, Psicología de C. G. Jung, Paidós, Barcelona.

Jaffé, Aniela, 1992, De la vida y la obra de C. G. Jung, Libro Guía, Madrid.

Jung, Carl Gustav, 2002, Psicología y alquimia, Trotta, Madrid. ,2006, Aión. Contribuciones el simbolismo del sí mismo, Paidós, Barcelona. , 2007, Respuesta a Job, FCE, México. et al., 2003, El hombre y sus símbolos, Caralt, Barcelona.

Ortiz Oses, Andrés, 1998, Jung, arquetipos y sentido, Paidós, Barcelona.

Poost, Laures van der, 1998, Jung y la historia de nuestro tiempo, Paidós, Barcelona. Vázquez Fernández, Antonio, 2002, Psicología de la personalidad en C. G. Jung, Paidós, Barcelona. 